\title{
MONTEIRO LOBATO E O PURISMO LINGÜÍSTICO
}

Marli Quadros Leite*

\section{Introdução}

Este artigo visa a analisar algumas posições de Monteiro Lobato sobre a língua portuguesa, para mostrar a variabilidade e a instabilidade desse autor em relação ao uso da língua, quando buscava encontrar o melhor meio de atingir seu público leitor. No início da carreira como escritor, a preocupação de M. L. era usar uma linguagem castiça, a mais próxima possível dos clássicos portugueses, depois, chegou à conclusão, não sem atravessar grandes períodos de conflito, de que a melhor linguagem é aquela que o público lê, compreende e gosta. Para mostrar essa trajetória de Lobato, escolhemos examinar a sua metalinguagem exposta nas cartas trocadas com um "amigo de literatura", Godofredo Rangel, publicadas nos livros A barca de Gleyre e Cartas escolhidas.

O ponto de partida para analisar o purismo nessa metalinguagem é o do conceito de purismo como fenômeno de preservação de norma. Em outros termos, tem-se como purismo a presença da diacronia na sincronia, ou a tentativa de manutenção ou fixação de uma norma contemporânea. Assim, o purismo apresenta características diferentes, a partir de sua origem: é ortodoxo, quando tentativa de preservação de norma culta prescrita na gramática tradicional; é nacionalista quando, por motivos políticos, é tentativa de preservação de norma usada por um povo; e heterodoxo, quando há características de ambos. Esse último tipo está presente, por exemplo, nos manuais de redação de estilo de grandes jornais, pois ao lado do veto a certos usos lingüísticos 
contemporâneos, em detrimento de outros já em estado de desaparecimento, há aceitação (e até mesmo recomendação) de certos vocabulários ou estruturas gramaticais não abonadas na tradição literária e, por conseguinte, na norma culta tradicional.

\section{Monteiro Lobato: conflito de posições}

O purismo ortodoxo denunciado por Lima Barreto foi também praticado por Monteiro Lobato, literato que criou polêmicas relativas tanto a suas atitudes políticosociais, quanto às relacionadas às letras. No âmbito sociopolítico, levantou questão sobre a pobreza e ignorância do homem do campo, quando criou Jeca Tatu, e sobre o problema do petróleo e do ferro brasileiros. Em relação às letras, suas opiniões sobre o uso da língua também marcaram época.

Por isso, o exame da metalinguagem produzida no século XX não pode excluir a produzida por Monteiro Lobato, entre os anos de 1904 a 1945. Em primeiro lugar, porque é significativa para a história da língua praticada no Brasil; em segundo, porque é abundante; em terceiro, porque reflete a indecisão e o conflito que envolveu o problema da constituição da norma brasileira.

A análise do discurso de Monteiro Lobato mostra como suas convicções lingüísticas eram temporárias e como eram destoantes o seu discurso e a prática. As mudanças de posição acerca do conceito de língua servem como linhas divisórias das fases por que passou. Adotou posição conservadora, mas reagiu à dureza de certas regras gramaticais em vigor. Preocupou-se com a prescrição gramatical, mas assumiu posição inovadora, rejeitando intensamente a prescrição. E, finalmente, retomou antigas posições, embora de modo menos rigoroso.

As fases lingüísticas de Lobato aparecem com nitidez em textos de diversa natureza. Como assinalou Pimentel Pinto (1994: 52), os textos do escritor paulista podem ser distribuídos em três grupos: "os de finalidade literária; os de finalidade pragmática, voltados para a defesa de idéias ou propostas; os de finalidade subjetiva - ou de expressão pessoal -, a sua riquíssima correspondência". O nosso interesse recai, predominantemente, nos trabalhos relativos a esse último grupo, na tentativa de mostrar, pela análise dos comentários lingüísticos, postos na correspondência pessoal do autor, sua concepção de língua e seu pensamento sobre a prática lingüística, o uso.

As cartas escritas a Godofredo Rangel, ao longo de 40 anos, colecionadas na obra A barca de Gleyre, constituem o nosso corpus principal. Esse material apresenta 
dupla vantagem: autenticidade, pois não havia, por parte dos correspondentes, até 1919, intenção de publicá-lo, e desenvolvimento cronológico claro. No entanto, não nos escusamos de utilizar textos de finalidade literária e pragmática, quando indispensáveis à nossa análise.

A metalinguagem de Monteiro Lobato traz características dos dois primeiros períodos do século. Essa é uma situação natural, já que viveu, e incorporou, as tendências de uma época extremamente marcada pela discussão a respeito do uso da língua.

Essa densidade diz respeito não somente à quantidade de textos produzidos, mas também à diversidade de fontes deles depositárias. Além dos comentários publicados pela imprensa, nos discursos proferidos por filólogos e interessados na língua de modo geral e nos textos especializados sobre o assunto, o texto literário, com muito maior freqüência que antes, passou a abrigar metalinguagem relativa ao português praticado no Brasil.

Decorre disso a dificuldade de organização do pensamento de Lobato sobre a língua portuguesa. Um método possível para levar adiante essa tarefa é investigar-lhe a produção a partir de duas vertentes complementares: a cronológica e a conteudística. Partindo, então, da linha cronológica, obtém-se a seguinte disposição temática da metalinguagem do autor:

- de 1904 a 1919 - apego, ora maior, ora menor, à prescrição gramatical;

- de 1920 a 1940 - rejeição à gramática, aceitação da variante brasileira da língua portuguesa, a que chamou "língua brasileira";

- de 1941 a 1945 - retorno à ortodoxia gramatical. Reconhece diferenças entre a modalidade escrita e a falada, mas não aceita muitas interferências desta naquela.

\subsection{Concepção de língua}

Os escritos de Lobato evidenciam o cuidado que sempre teve com a linguagem, em todas as fases por que passou. Nas cartas que escreveu a Rangel, há muitos comentários a respeito do estilo, da precisão e clareza da linguagem e da correção lingüística ${ }^{1}$. O trabalho lingüístico que empreendia para extrair bom efeito dos seus

1 “Na propriedade da expressão está a maior beleza; dizer “ 'chuva' quando chove - 'sol' quando soleja. É aí que entra exata na rosca o parafuso" (A barca de Gleyre: 23 ): 
LEITE, Marli Quadros. Monteiro Lobato e o purismo lingüístico.

textos foi penoso e custou muita leitura e estudo das obras dos clássicos portugueses (Camilo Castelo Branco - para ele o mais perfeito de todos - Frei Luís e Sousa, Bernardes, Fialho, Almeida Garrett, Herculano de Carvalho esses com referências explícitas nas cartas). Entre os brasileiros, admirava o classicismo português de Rui Barbosa, Euclides da Cunha e Machado de Assis, em quem reconheceu um estilo clássico suave, mais adequado ao gosto brasileiro.

Das cartas publicadas em $A$ barca também é possível entrever posições não somente lingüísticas, mas também político-filosóficas. A análise de tais posições mostra que o conflito e a inquietação característicos da personalidade de Lobato têm origem, também, nos textos que davam suporte a suas atitudes. Quanto à Filosofia, apoiava-se nas obras de Nietzsche, referindo-se muitas vezes a Assim falou Zaratustra. Como ele mesmo afirmava, sobre Filosofia, cada vez que lia Nietzsche, ficava "mais topetudo". O topete lingüístico era de Camilo que extraía: "Cada vez que mergulho em Camilo, saio de lá adiante eu mesmo - mais topetudo" (A barca: 259).

Politicamente, deixa expressa sua preferência pelo "ruismo", contra o "hermismo" . Nessa opção ficam argamassadas a admiração política e a lingüística por Rui, pois o considerava o clássico do Brasil, a quem se podia admirar. Veja a expressão do seu pensamento:

"Tens os discursos do Rui? Que maravilha! Que deslumbramento! que incomparável mestre e que artista de palavra! É o grande clássico que nos dispensa de lidar com os velhos clássicos — tudo que neles há de bom aparece em Rui, e melhorado. Tem todas as energias e todas as suavidades. Rui é um Everest." (A barca: 177, 15 set. 1909).

Lobato permaneceu partidário de Rui Barbosa durante o período de governo de Afonso Pena, de Nilo Peçanha e de Hermes da Fonseca. Três anos mais tarde,

“ 'Balbucio adorável'. É preciso expulsar do teu vocabulário este adjetivo que o Macuco e a pandilha do Brás puseram a perder. O 'adorável' está babado demais, gosmento. 'Doídas saudades': é um perigo este adjetivo; fatalmente o tipógrafo comporá 'doidas' e o revisor deixará passar. 'Espaços trêmulos de asas ruflantes': restos do nefelibata: coisa sonante harmoniosa, mas trop literaire. 'O baque dos monjolos percutia: acho o 'percutir' muito de gatilho de espingarda, muito metálico; monjolo é pau e um pau que bate noutro não percute, dá um choque balofo. O 'sem fim das colinas' está magnífico. É teu? Quanto ao fecho (a pergunta final), não compreendo bem a sua razão de ser. Tudo mais, ótimo.” (Op. cit. : 24)

2 Nome atribuído à corrente política favorável à candidatura de Hermes Rodrigues da Fonseca, defensora do retorno do "militarismo" ao poder, contra o "civilismo" defendido por Rui Barbosa, tamběm candidato a presidente para o quadriênio 1910-1914. 
porém, confessa a Rangel ter passado o seu "período febril" de ruismo. O motivo da dissensão foi político, mas implicou a indiferença pelos textos de Rui. Disse Lobato:

"Eu é que estou divorciado de Rui... por motivos bélicos. Eu não o leio. Como torço pela vitória da Alemanha e Rui é o paladino da derrota alemã, resumo a minha opinião sobre ele com a imbecilidade dum calouro: 'É uma besta!' ' (A Barca: 363, 11 out. 1917).

Quanto às convicções lingüísticas de Monteiro Lobato, pode-se dizer que a única constância foi a veneração que nutriu pelo estilo e linguagem de Camilo Castelo Branco. Nas fases de maior dependência da norma portuguesa, Lobato enalteceu Camilo incondicionalmente e o considerava modelar. Nas fases de menor dependência, estabelecia algumas restrições à exploração do texto camiliano, quando afirmava que o romântico português era fonte, mas seria preciso estar atento à contemporaneidade da linguagem que a vida estava a exigir. Sempre, no entanto, cobrava de Rangel, e de si próprio, que os clássicos, e em especial Camilo, não deviam ser imitados. Ao contrário, o objetivo era saírem mais individualizados depois de cada leitura. O que visavam a aprender nos clássicos era o estilo, os torneios de linguagem, o manejo e a experiência de produzir forte efeito de sentido até a partir da exploração de fatos banais da vida cotidiana, imperceptíveis ao homem comum.

Para Lobato, Camilo era o remédio para todos os males lingüísticos: a falta de vocabulário, a imprecisão das imagens verbais, a incorreção gramatical... Portanto, o romântico português foi útil em todas as fases da vida literária de Lobato, não importando se este estava mais ou menos afeito à "gramática". Por isso, na fase em que achava que o estilo, o vocabulário e a sintaxe de Camilo podiam ser recriados por ele, sem restrições, disse Lobato a Rangel:

"Confundes bobamente duas coisas: clássicos e Camilo. Camilo não é clássico no sentido gramaticóide do termo; e para afundarmos os dois no mar do classicismo, nunca te convidaria eu, porque os aborreço sobre todas as coisas. Convidei-te para o passeio através de Camilo como remédio contra o estilo redondo dos jornais, que somos forçados a ingerir todos os dias. Camilo é o laxante. Faz que eliminemos a 'redondeza'. É água limpa onde nos lavamos dos solecismos, das frouxidões do dizer do noticiário - e também nos lavamos da adjetivação de homens copados como Coelho Neto. Camilo é lixívia contra todas as gafeiras. E além desse papel de potassa cáustica, ele nos dá essa coisa linda chamada topete. Camilo nos 'desabusa', como aos semina- 
ristas tímidos um companheiro desbocado. Ensina-nos a liberdade de dizer fora de qualquer forma." (Grifos nossos) (A barca: 259).

E, em fase posterior, apresenta restrições ao exagero à imitação do literato português, quando fala a Rangel:

\begin{abstract}
"Hoje estás no ponto em que é só escrever e publicar: a crítica só terá carinhos com você. Uma coisa ainda aconselho: podar as camilices enxertadas na primeira parte. Estou convencido de que o vocábulo fora da moda, fóssil ou raro, é 'pedra' de banana-maçã. O teu estilo é o desta última parte. Nela não há ressaibo de Camilo nem de ninguém: tudo ali é Godofredo Rangel até o sabugo das unhas." (Grifos nossos) (A barca: 289, 01 ago. 1915).
\end{abstract}

A metalinguagem produzida por Lobato, embora extensa, não traz sinais de estudos teórico-filosóficos sobre língua, restringindo-se seus comentários à prescrição gramatical, ao estilo, ou uso da língua. Sobre o conceito de língua do autor, pode-se dizer apenas o que está subjacente a suas afirmativas. Nesse particular, Lobato deixou-se levar pelas correntes filosóficas da época, pelas quais se interpretava o mundo e, inevitavelmente, a língua. Isso quer dizer que se percebe em seus comentários a presença do evolucionismo, por meio do qual se acreditava que as línguas passavam pelo mesmo processo por que os seres vivos passavam: nascimento, crescimento, corrupção - em específico em relação às línguas - e morte. A propósito disso, escreveu:

\begin{abstract}
"Assim como o português saiu do latim pela corrupção popular desta língua, o brasileiro está saindo do português. O processo formador é o mesmo: corrupção da língua mãe. A cândida ingenuidade dos gramáticos chama 'corromper' ao que os biologistas chamam 'evoluir'." ("O dicionário brasileiro". In: Pimentel Pinto, 1981: 102)
\end{abstract}

Pelo discurso e prática do autor, a teoria evolucionista era a que realmente apoiava as suas idéias sobre a língua. Por isso, acreditava na pureza e impureza da língua e no seu desgaste pela ação dos que ignoram "a fase áurea do desenvolvimento da língua", representada nos textos de escritores antigos e clássicos. Desse modo, pode-se dizer que o autor pratica o tipo de purismo ortodoxo. Isto é, considerava superior a norma portuguesa, lutava para mantê-la e preservá-la e ridicularizava o uso brasileiro da língua, o que fica evidente em várias das suas afirmações, como por exemplo: 
"Num romance de Júlio Verne há um Thiago Paganel, geógrafo de má memória, ao qual sucedeu o caso, que hoje não me espanta, de aprender o espanhol pelo português. Quando deu pelo engano, abriu a boca. Não me espanto porque fiz o mesmo: aprendi por cá uma língua bunda pensando que era a nobre e fidalga língua portuguesa." (Grifos nossos) (A Barca: 191, 12 jan. 1910).

Em outras fases, nota-se avanço em relação à concepção de língua de Lobato. Um dos motivos que concorreram para isso talvez tenha sido o fato de ter aceitado a teoria determinista de Taine, que já conhecia, pois, em 1910, confessava a Rangel:

"E espero encomendas feitas a várias livrarias lusitanas que me abasteçam de Francisco Manoel, um sujeito que deve valer muitos Sthendais e Taines." (A Barca: 191, 12 jan. 1910).

Mesmo assim, os efeitos do determinismo só se fazem sentir mais vigorosamente a partir de 1940. Nessa época já era um escritor conhecido, há alguns anos, e havia entendido que o livro precisaria trazer linguagem atual e mais condizente com a realidade lingüística dos que usam cotidianamente a língua, para que o texto fosse aceito pelo público a que se destinava. Fica implícito, então, que o meio determinaria a linguagem a ser usada. Em outras palavras, a língua modificava-se se submetida a novo ambiente social, racial e geográfico. Sobre isso, Lobato afirmou:

"O português, no Brasil, está se modificando, e essa modificação se processa sem a menor unidade. Efetua-se ela ao sabor das diferenças mesológicas, raciais, sociais. Se essas diferenciações não forem neutralizadas por uma força mais forte, então o 'brasileiro' degenerará em inúmeros dialetos." (Grifos nossos) ("Prefácio", Folha da Manhã, 1943. In: Pimentel Pinto, 1981: 79).

Observe-se, na citação, que o autor não se libertou de suas convicções evolucionistas, apenas acresceu a ela a certeza do determinismo. Desse modo, continuava acreditando na degeneração da língua e na ação benéfica, conservadora, da norma tradicional, "a força mais forte", segundo a qual "escritores de alto coturno" ajudam a preservar a língua.

Pelo visto, o tratamento que Lobato dispensou à língua foi impressionístico ${ }^{3}$. Como ele mesmo afirmou várias vezes, em matéria de língua, guiava-se pelo "tato e

3 As opiniões sobre língua nesse período são, predominantemente, impressionistas. No entanto, existem especialistas que também escrevem sobre o assunto, dos quais podemos destacar: 
LEITE, Marli Quadros. Monteiro Lobato e o purismo lingüístico.

faro". A relevância que Lobato deu ao assunto pode ser explicada por dois fatores: interesse pessoal pela literatura e, portanto, pelo aperfeiçoamento do uso e exploração do instrumento de trabalho, e influência das discussões sobre temas sociopolíticos da época.

Quanto a isso, não se pode negligenciar que, desde o século XIX, fatores político-sociais (como a Abolição da Escravatura, a Independência e a Proclamação da República) levaram, pelo menos superficialmente, os brasileiros à afirmação da nacionalidade ${ }^{4}$. Esse sentimento fez-se realidade, primeiro, no Romantismo, quando a fala regional invadiu a literatura, mesmo tendo sido, nesse momento, como denuncia Sodré (1976: 199-230), apenas a "exaltação do pitoresco" e não a verdadeira representação da fala popular.

Com José de Alencar iniciou-se a discussão sobre a prática lingüística brasileira: surgiram na literatura tupinismos e neologismos literários, arduamente combatidos pelos mais conservadores. Nesse período, o lugar das discussões eram os jornais, as revistas e os discursos. Começa, ainda devagar, a vigorar uma atitude antilusista baseada nos "ideais libertários".

À exceção de Recordações do escrivão Isaías Caminha, de Lima Barreto, publicado em 1909, somente a partir de 1922 a metalinguagem passa a ocupar os textos literários. Monteiro Lobato e Manuel Bandeira inauguram a nova tendência: aquele publica o conto "O colocador de pronomes" e este, "Poética" e "Evocação do Recife". Depois desses, surgem muitos textos literários que tratam do problema, especialmente os dos modernistas, cujo objetivo era destruir o passadismo e reafirmar a nacionalidade brasileira ${ }^{5}$. Também é nessa ocasião que os jornais deram mais espaço à publicação de crônicas e comentários sobre o problema lingüístico brasileiro" .

Como toda ruptura é difícil e polêmica, investiu-se muito na discussão sobre a língua, em especial sobre a denominação da língua praticada no Brasil (língua brasileira, idioma nacional, língua pátria, língua nacional) e sobre as diferenças léxicas e gramati-

Amadeu Amaral, Sousa da Silveira, Antenor Nascentes, Júlio Ribeiro, Serafim da Silva Neto, Clóvis Monteiro.

4 Nessa época, houve apenas, conforme registra Sodré (1976:207-09) independência política, porque intelectualmente continuávamos colônia, menos de Portugal e mais da França.

5 Sirvam de exemplo: Poesias completas, O empalhador de passarinhos, de Mário de Andrade; República dos Estados Unidos de Brasil, de Menotti Del Picchia; Quatro poentas, de Brasil Pinheiro Machado; Poesias humorísticas, de Bastos Tigre.

6 Cf. Pimentel Pinto, 1981:XLIV-XLV. 
cais do português brasileiro, frente ao português. O resultado, pois, não poderia ser outro senão a incorporação do tema por aqueles participantes da vida cultural do país.

Vemos, portanto, que Lobato sofreu a pressão de duas atitudes lingüísticas conflitantes. A primeira foi a da norma portuguesa que vigorou do final do século XIX até os anos 20 do século seguinte. A segunda, conseqüente dessa, foi a revolta contra o apego à norma portuguesa, primeiramente denunciado por Lima Barreto e, depois, pelos modernistas.

Lobato não demonstrou força suficiente para sustentar uma ou outra dessas causas. Vacilou. Em alguns momentos praticou purismo ortodoxo, em outros, nacionalista, sem apresentar, nos comentários sobre a língua, posição definitiva para um ou outro. No fundo, porém, sempre foi purista ortodoxo, cujas bases foram minadas pela divulgação de novas idéias sobre a língua e pela verificação de que a literatura que atinge o povo tem de ser vazada em linguagem que ele compreenda, isto é, que lhe seja contemporânea, como passaremos a mostrar em pormenor.

\title{
1.2 Lobato e o purismo
}

É preciso registrar que Lobato, antes de "apaixonar-se" pelo português, de Portugal, não considerava ser essa língua suficientemente formada para expressar grandes sentimentos, como as literaturas estrangeiras o faziam. Também sobre isso foi drástico: primeiro valorizou as literaturas estrangeiras, russa e inglesa, em detrimento da portuguesa; depois, recusou-se a ler outras línguas, pois era o português que queria "aprender", pela literatura portuguesa. Em 1907, dizia a Rangel:

\begin{abstract}
"Não te posso dizer nada sobre Crime e castigo porque não há falar de coisas grandes com meios pequenos - com estas pulgas glóticas que são as 'palavras em língua portuguesa', esse produtinho lá de Portugal, onde também fazem tamancos e palitos. A nossa análise está aparelhada com medidas francesas, decimais - um sistemazinho decimal de idéias. Não pode, pois, não tem jeito, não consegue dar idéia das coisas russas. Quando leio as outras literaturas, eu sinto isto e aquilosentimentos analisáveis e classificáveis. Quando leio os russos, eu pressinto. Guerra e paz!... Crime e castigo! Casa dos mortos! Gorki Gogol - Turguenef - todos..." (A barca: 123, 31 ago. 1907).
\end{abstract}

Pouco mais tarde, já tinha mudado de opinião, e alçado o português à posição de língua apta à expressão literária: 
"Parei com as minhas leituras de língua estrangeira. Não quero que nada estrague minha lua de mel com a língua lusíada, que descobri como o Nogueira descobriu a Pátria e o Macuco o verbo 'apropinquar'. E sabe o que mais me encantou no Português? Os idiotismos. A maior beleza das línguas está nos idiotismos e a língua lusa é toda um Potosi." (A barca: 175, 15 set. 1909).

Quando acreditou no português como língua de expressão literária, Lobato incorporou todas as tendências caracterizadoras do purismo ortodoxo do começo do século. Assumiu ser o português europeu dos escritores antigos, clássicos e modernos (até o Romantismo) o "bom e correto português" e que toda linguagem em desacordo com ele era impura e representava corrupção ao "vernáculo" (de Portugal). São inúmeras as passagens em que reafirma esses pressupostos, vejamos algumas, a título de exemplo:

"O mau português mata a maior idéia, e a boa forma até duma imbecilidade faz uma jóia.” ( $A$ barca: 145, 01 nov. 1908).

"Precisamos ler Camilo. Vou mandar vir um sortimento. Saber a língua é ali! Camilo é a maior fonte, o maior chafariz moderno donde a língua portuguesa brota mijadamente, saída inconscientemente, com a maior naturalidade fisiológica. Eu tenho a impressão de que os outros aprenderam a língua e só Camilo a teve ingênita até no sabugo da unha de todas as células do corpo." (A barca: 166, 07 jul. 1909).

"Vou atacar uns livros tremendos: Anais de D. João III, de Frei Luís de Souza e Vida de S. Francisco Xavier, de Lucena. Também vou afundar na História Universal de Laurent.” (A barca: 172, 02 set. 1909).

"A mim me faltam muitas leituras, mais, mais Camilo, talvez o Bernardes da Nova Floresta. Que bem escreve esse raio de padre! Como deliberei aprender a língua de ouvido, e meu ouvido é lerdo, despendo mais trabalho que os que vão logo às regras - à Gramática. Terminada a lição de Camilo e Bernardes, esses dois colossos, tentarei produzir algo. Por ora o que me sai são uns contitos de pé quebrado - e vejo você sabedor da língua e acorrer!" (A barca: 327, 30 ago. 1916).

Lutar contra o galicismo foi uma das maiores bandeiras dos puristas ortodoxos do começo do século. Monteiro Lobato foi "anti-galicista" e essa foi a contraparte ideológica de seu purismo. O antigalicismo era uma briga de Portugal, que não queria se submeter, também na língua, ao domínio francês já existente na esfera políticoeconômica. Por extensão, e não por convicção, os brasileiros reagiam contra esse domínio. No Brasil, segundo assinala Sodré (1976: 208), o que ocorria era uma trans- 
plantação cultural de influência predominantemente francesa, abraçada pelas classes proprietária e intelectual. Iniciada em meados do século XIX, com o Romantismo, esse domínio estendeu-se até início do século XX.

Lobato chamou a si a briga contra "a francesia" e por isso rejeitava violentamente não apenas as palavras e expressões que "cheiravam a francês", mas tudo o que viesse da França. "Abaixo a francesia" era palavra-de-ordem do escritor. Essa posição está documentada em toda a sua obra, quer de caráter pragmático, subjetivo ou literário. Como exemplo, apresentamos um trecho registrado em A barca de Gleyre:

\begin{abstract}
"Também vou com o Nogueira no relativo à linguagem. Limpe-a do 'insucesso', do 'banal' e do mais que cheirar a francês. Abaixo a França! A minha germanofilia me está beneficiando o vocabulário. Da antipatia pelo gaulês passei à execração do galicismo; e se de passagem pilho-o, mato-o entre as unhas como a um piolho." (Op. cit.: 324, 30 ago. 1916).
\end{abstract}

No livro As Idéias de Jeca Tatu, cuja primeira edição é de 1919, Lobato ainda blaterava contra o francesismo. Por isso, afirma:

"Arinos enfrentou a corrente desbragada da francesia; mostrou como
era grotesco o pastiche invasor, contrapondo-lhe uma obra profunda-
mente racial." ("A Criação de Estilo". In: As Idéias de Jeca Tatu: 28)

O livro As Idéias de Jeca Tatu traz prefácio em que se explica a aversão de Lobato pelo francesismo. Lê-se lá que a assimilação da cultura francesa representa "a nossa completa anulação de personalidade diante da França” e que Jeca, coitado, representa os "macacões" plagiadores, que têm como língua o "patuá senegalesco".

Em "Curioso caso de desmaterialização", Lobato conversa com a "sombra" de Camilo, para ouvir dele toda a indignação quanto à "parvoiçada" em que se encontrava a língua portuguesa, com a qual entrou em contato, no Brasil, por meio de um pequeno anúncio de restaurante. Depois de procurar informar-se a respeito da "macaquice" que é a mistura de português-inglês-francês do anúncio, disse a sombra:

"Sabe que mais? Vou desmaterializar-me já e já; volto aos intermúndios e lá darei à sombra de Cabral pêsames pela asneira que praticou. Receio que dêem vocês de criar pêlo no corpo e vos nasçam caudas no cóccix, e se ponham todos de repente a marinhar árvores acima com bananas na munheca - desmentindo Darwin. $\mathrm{O}$ inglês pôs o macaco 
LEITE, Marli Quadros. Monteiro Lobato e o purismo lingüístico.

no começo da evolução: vocês provam que ele acerta melhor pondo-o no fim. Au revoir!" ("Curioso caso de desmaterialização". In: As Idéias de Jeca Tatu: 135)

O método usado por Lobato para conservar a norma portuguesa no Brasil era “joeirar” a linguagem portuguesa, de Camilo Castelo Branco, principalmente, e de outros grandes escritores da literatura portuguesa da época, citados anteriormente. "Joeirar" significa ler, anotar para assimilar a forma da frase e o tom das palavras, não para decalcar, dizia ele, mas para imitar criando? .

A tarefa de imitar a norma portuguesa, entretanto, não era tão fácil. Se Lobato não estivesse imerso na comunidade lingüística brasileira, em que atuava como agente e paciente da história, talvez conseguisse êxito total quanto ao intento de praticar completamente a língua de Portugal. Todavia, mesmo mergulhado em Camilo até sentir engulho, a língua da sua comunidade lingüística aparecia, até quando rejeitada. Isso se faz sentir, por exemplo, no caso da colocação dos pronomes, que foi a grande preocupação dos puristas dessa fase ${ }^{8}$.

É inegável que Lobato usava linguagem ao gosto da época. Tanto isso é verdade que arrancou elogios de Rui Barbosa, o que foi providencial para sua literatura, pois, a partir desse fato, seus livros começaram a ser procurados. Mesmo assim, escapavam-lhe alguns pronomes que teimavam em não aparecer no lugar, apesar do joeiramento lingüístico nos grandes mestres portugueses. Resolveu, então, dar seus

7 "O meu processo é anotar as boas frases, as de ouro lindo, não para roubá-las ao dono, mas para pegar o jeito de também tê-las assim, próprias. Dum de seus livros extraí 60 frases de encher o olho. Não releio o compendiado, o extrato, e aspiro o perfume e me saboreio. Formo assim um florilégio camiliano do que nele mais me seduziu as tripas estéticas. E não discuto nem analiso botanicamente um cravo ou uma gostosa laranja mexeriqueira. Cheiro um e como a outra.

Resumindo: meu plano é ter uma horta de frases belamente pensadas e ditas em língua diversa da língua bunda que nos rodeia e nós vamos assimilando por todos os poros da alma e do corpo." (A barca: 257, 16 jan. 1915).

8 Entre os puristas, destaca-se Cândido de Figueiredo que escreveu as séries $O$ que se não deve dizer, Lições práticas de português, além de Estrangeirismos e O problema da colocação de pronomes. Outro que pode ser citado é Carlos Góis que escreveu Dicionário de galicismos. Registre-se que como vigorava o império da norma clássica, mesmo autores que não tinham índole purista, como Antenor Nascentes, publicou obra com tal característica, intitulada $\mathrm{Di}$ cionário de dívidas e dificuldades do idioma nacional, não sem antes justificar-se na Introdução: "Embora não concorde com todas as pequeneses inventadas pelos puristas, exponhoas para livrar o candidato [o aluno] de incorrer na pecha de ignorá-las". 
textos à correção de Godofredo Rangel, que, pelo que se pôde depreender, era mais afeito aos estudos das prescrições gramaticais e, portanto, podia receber a incumbência de fazer a revisão de seus pronomes ${ }^{9}$.

"Estou com uma idéia: não mando mais nada sem um repasse aí pela tua fieira ou crivo, porque me envergonho muito quando me escapam deslizes, sobretudo maus pronomes. Como é dificil esta peste de língua portuguesa! Haverá alguma pior?" (A barca: 332, 12 set. 1916) (Grifos nossos).

A observação final do autor, nesse trecho, merece comentário. Primeiro por partir de alguém que, além de interessado nas questões de língua, foi estudioso. Foi leitor atento de inúmeras obras literárias portuguesas, mas como ele mesmo disse, apenas com intuito de ver atenuada a sua culpa pelos deslizes gramaticais. Até então lia obras francesas e pouquíssimas portuguesas; como exemplo, citou Eça, Camilo e Machado de Assis. Segundo, porque a dificuldade a que se refere o autor não é quanto ao uso do português, mas ao uso do português de Portugal, do qual não era usuário nativo. Escapam-lhe, portanto, nuances e sutilezas da variante brasileira. Ao contrário, as peculiaridades da língua praticada no Brasil, se em confronto com as de Portugal, aparecem como erros. E o conflito fica estabelecido.

A instabilidade da atitude lingüística de Lobato é clara, porque, ao mesmo tempo em que lamentava a dificuldade da língua e buscava a solução de problemas de prescrição gramatical, rejeitava a gramática (o motivo maior da revolta contra a gramática foi uma reprovação em português, quando adolescente). Nesse caso, entretanto, o discurso e a prática estavam divorciados. As palavras negavam a importância e a força da prescrição gramatical que, por essa época, era completamente fundada na língua escrita literária do passado português. A ação de Lobato, todavia, traía o discurso e ele corria atrás das regras gramaticais, por meio da "garimpagem" no texto literário em que, além do estilo buscava as constâncias lingüísticas - as regras gramaticais, portanto -, e por meio de consultas a Rangel, sempre bem informado acerca da norma prescritiva. Contra a gramática, esbraveja nos seguintes termos:

"Grande bem me fazes com as denúncias das ingramaticalidades. De gramática guardo a memória dos maus meses que em menino passei

9 Ao longo do livro $A$ barca de Gleyre, Lobato afirma várias vezes que Rangel era afeito aos estudos gramaticais e, por isso, estava apto a corrigir-lhe os "erros de português". 
decorando, sem nada entender, os esoterismos de Augusto Freire da Silva. Ficou-me da 'bomba' que levei e da papagueação, uma revolta surda contra gramáticas e gramáticos, e uma certeza: a gramática fará letrudos, não faz escritores." (A barca: 268, 30 set. 1915).

Todavia, menos de um mês depois, dizia a Rangel:

"Est modus in rebus - nem tanto a Cândido nem tanto a Graça. Olhe que se este nos autoriza ao 'fazer com que', ao 'cumprir com o dever' etc., é o caso de nos mudarmos para o bairro dos que o não autorizam. Há sempre uma alta nobreza no estilo que se põe nos moldes sintáticos dos grandes antigos, procurando tomar como regra o que neles for regra, e não se autorizando a constituir como regra geral uma exceção, uma cinca, um desleixo de Vieira ou de Camilo, quando é certo que até Homero cochilava". (A barca: 272, 23 out. 1915).

Aí está o exemplo da busca das regras prescritivas por outra via que não o livro, o manual, onde estão codificadas todas elas. Não fosse ele, realmente, muito apegado à norma gramatical, procuraria a força expressiva da sintaxe já usada no Brasil, como, por exemplo, a colocação dos pronomes cujas regras não correspondem à portuguesa, ou a regência de alguns verbos, a exemplo de chamar e pedir.

Depois de 1920, Monteiro Lobato acentuou o tom das críticas à gramática. Nessa época a renovação nos estudos lingüísticos já começava a se fazer sentir e o radicalismo em torno da linguagem portuguesa, em detrimento da brasileira começava a ficar ridículo ${ }^{10}$. Lobato também, acompanhando a tendência da época, mudou um pouco o seu discurso, acentuando as críticas à gramática.

Em 1917, Lobato já havia pensado em escrever o conto "O colocador de pronomes”, em que a personagem apresenta a paranóia lingüística da colocação dos pronomes à moda portuguesa e termina morrendo por causa de um pronome mal colocado. O conto foi publicado em 1920. Em 1918, havia lido Recordações do escrivão Isaías Caminha, de Lima Barreto, e não fez restrições à linguagem do autor, criticada

10 Por essa época a discussão sobre a língua do Brasil já havia começado. Amadeu Amaral publicou parte da obra - a introdução e o primeiro capítulo - O dialeto caipira, na Revista Brasileira, em 1916, mas publicado inteiramente em 1920. Esse foi o livro que, a partir da orientação da Dialetologia, trouxe idéias renovadoras sobre o português do Brasil. Em 1919 veio a público o Trechos seletos e, em 1920, A língua nacional e seu estudo, de Sousa da Silveira. 
na época por conta de "alguns deslizes". Ao contrário, Lobato gostou do texto e o elogiou a Rangel ${ }^{11}$.

As idéias de Lima Barreto, no entanto, não influenciaram tanto Lobato, pois, numa atitude aparentemente jocosa contra o purismo ortodoxo e contra a escravidão que a sintaxe pronominal e outros temas gramaticais lhe impunham, anunciou ao amigo correspondente que em próximo livro (publicara Negrinha em 1919) colocaria um prefácio nos seguintes termos:

\title{
"CHAMINÉS
}

Contos de Monteiro Lobato, com pronomes por

Álvaro Guerra; com a sintaxe visada por José

Feliciano e a prosódia garantida no tabelião por

Eduardo Carlos Pereira. As vírgulas são do

insigne virgulógrafo Nunálvares, etc.

Tudo gente da mais alta especialização - e a crítica que se engalfinhe com eles. Isso, para não haver hipótese de me sair coisa vergonhosa como a primeira edição de Idéias de Jeca Tatu." (A barca: 403, 17 jan. 1920).

Se assim o fizesse, estaria isento da culpa dos deslizes gramaticais e de acordo com a tradição da língua lusitana! Essa era a intenção. Desse modo, não vivenciaria outra vez a experiência por que passou quando As Idéias de Jeca Tatu estavam no prelo e ele resolveu dar uma olhada no material. Lá verificou grande quantidade de erros, mas não os pôde corrigir. Não havia sido feita a revisão. O sentimento que teve no momento está descrito no seguinte passo:

\begin{abstract}
"Li várias páginas e corei até a raiz da alma. Não tinham feito revisão nenhuma. Erros indecorosos pululavam ali como pulga em cachorro sarnento. Corrigi o que pude. Era composição manual - uns tipos velhos, desbeiçados, indecentes. Tudo indecente. Estive lá até meia noite caçando pulgas no resto, mas desanimei: havia mais pulgas que estrelas no céu. Mandei tudo para o inferno e fui dormir." ( $A$ barca: 403, 17 jan. 1920) (Grifos nossos).
\end{abstract}

1 "Como ainda estou de resguardo e preso em casa, leio como nos bons tempos de Taubaté. Fechei neste momento um romance de Lima Barreto, Isaías Caminha. É dos tais legíveis de cabo a rabo. Romancista de verdade." (A barca: 384, 24 nov. 1918). 
De 1920 a 1940, Lobato sustentou sua crítica à gramática. A influência das novas idéias exerce-se sobre ele que, além de defender a idéia da língua brasileira, pensa em publicar uma gramática brasileira e também um dicionário brasileiro. Assim, em 1921, no artigo "Gramática Portuguesa”, afirma:

\begin{abstract}
"A língua brasileira está a sair das faixas, e coexiste no Brasil ao lado da língua portuguesa - como filha que cresce ao lado da mãe que envelhece. Tempo virá em que veremos publicar-se a Gramática Brasileira. Pois bem: a gramática de Firmino Costa, sem que o autor pensasse nisso, é já um bom passo à frente para a criação da gramática brasileira." ("Gramática Portuguesa". In: Pimentel Pinto, 1981: 54. vol. II).
\end{abstract}

Na mesma trilha, no artigo "O dicionário brasileiro", de 1921, prega a necessidade da elaboração de um dicionário que apresentasse a neologia, os regionalismos e tupinismos brasileiros.

"Não há documentos, mas é provável que o primeiro brasileirismo
surgisse exatamente no dia 22 de abril de 1500 . E desde então não se
passou um dia sem que a língua do reino não fosse na colônia infiltrada
de vocábulos novos, de formação local, ou modificada na significação
dos antigos." ("O dicionário brasileiro". In: Pimentel Pinto, 1981: 58).

Em outro texto, defende a língua falada e argumenta sobre a diferença entre as modalidades falada e escrita:

"A correção da língua é um artificialismo, continuei episcopalmente. O natural é a incorreção. Note que a gramática só se atreve a meter o bico quando escrevemos. Quando falamos, afasta-se para longe com as orelhas murchas. Na linguagem falada, a não ser na boca dum certo sujeito que conheço, o verbo concorda ou não com o sujeito - à vontade (e repetir a frase para restaurar uma concordância é pedantismo). (...) Em oposição a essa língua freqüentíssima, tão pitoresca, toda improvisações e desleixos, com todas as cores do arco-íris, todos os cheiros e todos os sabores, temos a língua escrita, emperrada, pedante, cheia de 'cofos' e 'choutos'." ("Prefácio de 'Éramos Seis' da Sra. Leandro Dupré". In: Pimentel Pinto, 1981: 79).

No que diz respeito à sintaxe de colocação e uso do pronome sujeito em função de objeto, resume: 
"Não obstante, a corrente do ele cresce dia-a-dia e acabará expungindo о $o . "$

"A língua é um meio de expressão. Modifica-se sempre no sentido de aumentar o poder de expressão. A variedade de coisas novas que tivemos necessidade de expressar, num mundo novo como o Brasil, forçou no povo um surto copiosíssimo de vocábulos. (...) Os bons [vocábulos], os expressivos, vencem, ficam aquartelados na língua. A princípio na língua falada. Depois penetram na chamada literatura regional. Daí passam aos glossários de brasileirismos e entram, por fim, consagrados, no panteon dos dicionários." ("O dicionário brasileiro". In: Pimentel Pinto, 1981: 54).

A última posição de Lobato diante da língua portuguesa foi conservadora, embora menos radical do que a primeira. Em verdade, depois de uma fase de revolução, Lobato tinha uma de reação. Portanto, após defender a língua brasileira, chegou à conclusão de que ela não existia:

"Mesmo assim posso dizer-lhe que ao meu ver não existe uma língua brasileira. Existe, sim, no Brasil, uma língua em muitos pontos diversa da que se fala em Portugal" ("Língua Brasileira". Entrevista ao repórter de A Folha da Manhã, em 1941. In: Pimentel Pinto, 1981: 75).

Havia, então, entendido que o que havia era a língua portuguesa, com variações decorrentes de fatores geográfico-sociais. Mesmo assim, não adotou posição completamente liberal em relação à língua, mas também não voltou totalmente à ortodoxia inicial. Seu pensamento evoluiu em muitos pontos. Verbalizou suas conclusões sobre as duas modalidades lingüísticas, a falada e a escrita, reconhecendo ser aquela mais assimilada pelo público.

Esse fato o levou à prática da língua "desliteraturizada" nos seus livros infantis, para que fossem compreendidos pelas crianças. E esse foi o "filão" que encontrou. Chegou a afirmar a Rangel que "desgraça da maior parte dos livros é o excesso de literatura". Esse é o pensamento que transparece na pequena fábula que conta, a propósito de um livro do amigo correspondente:

\footnotetext{
"Aquilo é formidável; se o público não se apressa, é que a 'quantidade' sempre desprezou a 'qualidade'. Para tudo há uma fábula. O galo encontrou uma pérola. 'Antes fosse um milho', disse e passou. Você deu pérola ao galo. Eu dou milho eis a razão do meu sucesso. Mas eu dou milho, meu caro Rangel, por uma razão muito simples: incapacidade de dar pérolas..." (A barca: 420, 30 jun. 1921).
} 
Mais contundente ainda está no trecho seguinte sobre o combate à literatura:

\begin{abstract}
"Não imaginas a minha luta para extirpar a literatura dos meus livros infantis. A cada revisão nova nas novas edições, mato, como quem mata pulgas, todas as 'literaturas' que ainda as estragam. Assim fiz no Hércules, e na segunda edição deixá-lo-ei ainda menos literário do que está. Depois da primeira edição é que faço a caçada das pulgas - e quantas encontro, meu Deus!" (A barca: 372, 10 dez. 1945, v.2 ).
\end{abstract}

A "literatura" é exatamente o estilo, a sintaxe e o vocabulário à moda portuguesa, que ele tanto sofreu para aprender e dominar... A linguagem, enfim, destoante da realidade brasileira e que, por isso, precisava ser atualizada.

Todos esses avanços não implicam que Lobato tivesse aceitado e praticado uma linguagem livre de regras. Ao contrário, o reconhecimento das diferenças entre a língua escrita e a falada o autorizara a pleitear sempre a correção da linguagem, na língua escrita, sem, no entanto, os exageros que se cometeram outrora, mas nunca deixou completamente de ser um purista ortodoxo.

\title{
1.3 Lobato e o Modernismo
}

Explicitamente, Lobato foi anti-modernista. Isso é o que mostra a superfície de sua metalinguagem, pois em várias oportunidades declarou-se contrário aos princípios do movimento. A primeira vez o fez ao criticar duramente a arte de Anita Malfatti. Foram essas as palavras que traziam a súmula do pensamento do autor sobre esse assunto:

\footnotetext{
"Entretanto, seduzida pelas teorias do que ela chama de arte moderna, penetrou nos domínios dum impressionismo discutibilíssimo, e pôs todo o seu talento a serviço de uma nova espécie de caricatura." ("Paranóia ou mistificação?’. In: As Idéias de Jeca Tatu: 61).
}

Em relação à literatura e uso da língua, não emitiu opinião sobre a ação dos modernistas, mas vê-se que acompanha o movimento e mantém contato com artistas nele envolvidos, como Graça Aranha, Ronald de Carvalho, Ribeiro Couto e Paulo Duarte, todos citados nas cartas de $A$ barca. Sobre o Modernismo, no entanto, falou, reclamou da importação de arte, da reprodução de padrões europeus. Para o Brasil, queria o brasileiro, dizia, e era intransigente. 
Embora tivesse idéias parecidas com as defendidas no Modernismo, em alguns pontos, por exemplo, na questão da defesa da "língua brasileira", Lobato não foi modernista. Como acentua Cavalheiro (1955: 300), o artigo de Lobato sobre Malfatti foi o motivador "de toda a má vontade de alguns modernistas contra o autor, origem e causa de longo e melancólico mal-entendido". Em nota, inclusive, Cavalheiro registra que "espíritos superiores como Mário de Andrade e Manuel Bandeira jamais perdoaram a Monteiro Lobato o artigo sobre Anita Malfatti”. E diz ainda que Mário não cita Lobato como escritor nem depois de este se ter esforçado, quando estava nos Estados Unidos, para que Macunaíma fosse traduzido para o inglês. Embora o reconhecimento público ao escritor não tivesse sido enunciado, pela ajuda quanto à tradução de Macunaíma, Mário enviou-lhe carta datada de 31 de agosto de 1931, para agradecerlhe, desejando que retornasse logo ao Brasil, a fim de dar "prô Brasil uns novos Urupês" (Op. cit.: 712).

Paradoxalmente, no entanto, em alguns aspectos Lobato tinha idéias parecidas com as modernistas, com muita antecedência em relação à eclosão desse movimento. Foi nacionalista, embora não exatamente com os mesmos ideais que os modernistas, mas bradou contra a importação de padrões europeus, quer na arquitetura quer na literatura, ou nas artes de modo geral. No campo das letras, pode-se dizer que renovou o terreno em duas frentes: a temática e a lingüística, ainda que de modo conflituoso. Lobato tinha personalidade indecisa e inconstante, o que se faz sentir na sua obra.

Em específico, quanto à linguagem de Lobato, há um movimento de fluxo conservador e refluxo renovador, que se mostra na mistura de estilo clássico, português, e moderno, brasileiro. Por isso Cavalheiro (1955: 288) diz que Lobato tinha um "estilo clássico dos grandes narradores, mas que buscou sempre clareza e simplicidade". Essas qualidades, porém, não foram plenamente atingidas. Em Urupês, Lobato "era uma mistura de camilismo e caipirismo", o que representou um refluxo em relação a Cidades mortas ${ }^{12}$; já em Negrinha e em $O$ Macaco que se fez homem quase atingiu o ideal desejado (Op. cit.: 290).

Pimentel Pinto (1994: 55-9), ao analisar a posição de Lobato, deixa claro o motivo que o levou a essas inconstâncias. É que viveu na época em que o padrão da "boa literatura" era o português dos clássicos europeus. Portanto, como já comentamos, estudava Camilo com intenção de chegar àquele estilo pelo caminho brasileiro, sem nunca deixar de ser "bestialmente Lobato". Isso resultou no seguinte quadro da

12 Conforme adverte Pimentel Pinto (1994:52), Cidades mortas foi publicado em 1919, depois, portanto, da primeira edição de Urupês, 1918, mas traz muitos contos anteriores a essa data. 
prática literária de Lobato: $1^{a}$ fase - uso de lusismos vocabulares, sintáticos e prosódicos, e ausência de neologismos, em Urupês; $2^{a}$ fase - desativação de lusismos, a partir dos anos 20, uso de neologismos, que marcaram a sua literatura (ib.). Essa última fase corresponde ao "abrasileiramento" da linguagem, o que correspondia, objetivamente, à utilização lexical típica do Brasil, mas, sempre, com sintaxe de acordo com a dos padrões tradicionais, embora sem inversões radicais que complicassem a frase.

Ainda segundo Pimentel Pinto (Op. cit.: 60), o abrasileiramento da linguagem de Lobato é visível na literatura infantil. Realmente, a literatura infantil deu a Lobato o que ele sempre procurou: vender muitos livros, ser um sucesso comercial. Não são poucos os registros em que declara estar à procura de uma fórmula que dê certo comercialmente, e a literatura sem literatura era o que o povo poderia aceitar. É o que está dito a Rangel:

"Quem sabe pode e quer você empreitar um serviço de que precisamos? Pretendemos lançar uma série de livros para crianças, como Gulliver, Robinson, etc. os clássicos, e vamos nos guiar por umas edições do velho Laemmert, organizadas por Jansen Müller. Quero a mesma coisa, porém, com mais leveza e graça de língua. Creio até que se pode agarrar o Jansem como 'burro' e reescrever aquilo em língua desliteraturizada - porque a desgraça da maior parte dos livros é sempre o excesso de 'literatura'. Comecei a fazer isso, mas não tenho tempo; fiquei no primeiro capítulo que te mando como amostra. Quer pegar a empreitada?" (A barca: 419).

"Estou a examinar os contos de Grimm dados pelo Garnier. Pobres crianças brasileiras! Que traduções galegais! Temos de refazer tudo isso - abrasileirar a linguagem." (A barca: 453).

"A coisa [literatura infantil] tem de ser narrativa a galope, sem nenhum enfeite literário. $\mathrm{O}$ enfeite literário agrada aos oficiais do mesmo ofício, aos que compreendem a Beleza literária. Mas o que é beleza literária para nós é maçada e incompreensibilidade para o cérebro ainda não envenenado das crianças." (A barca: 453).

Mesmo com essa certeza, não foi fácil quebrar a expectativa lingüística que vigorava em sua época ${ }^{13}$. Por isso, Preti (1990b: 35) registra que tanto as traduções de

13 Segundo Preti (1990b:35), cada época é marcada por um ideal lingüístico com o qual os textos devem estar em conformidade para serem aceitos. A propósito disso, diz o autor: "Os mecanismos de aceitação ou rejeição linguística agem mais ou menos como os mecanismos morais. Comportamentos que nos espantavam até recentemente, hoje são tidos como nor- 
Lobato, quanto as de Rangel ainda eram fiéis a um ideal que correspondia às expectativas lingüísticas da época. Assim, mesmo desliteraturizada, os diálogos de textos destinados ao público infanto-juvenil ainda eram artificiais. Lobato traduziu assim um diálogo do livro $O$ lobo do mar, de Jack London:

" - Gosto muito da senhora para magoá-la de qualquer maneira, respondeu Larsen com uma ternura que me fez estremecer. Mas não o faça, que o senhor Van Weiden pagaria com a vida." (Op. cit.).

Também é Preti (Op. cit.) que chama a atenção para o modo como Godofredo Rangel traduziu um diálogo de A Itha de Coral, de Robert Ballantyne:

“-Oh! rapazes! Achei! exclamou Jack erguendo-se; e indo cortar um galho em uma moita próxima, desnudou-o. Recordo-me de haver visto fazerem isto em nossa terra." (Op. cit.).

Nesse campo, o das traduções, então, podemos verificar a existência de mais uma contradição no discurso de Lobato. Em ambos os casos, explica Preti (Op. cit.), as opções lingüísticas dos tradutores ("mas não o faça", "haver visto fazerem”, "dêemme o cordel") não representavam a língua falada da época. Estavam, sim, de acordo com a expectativa lingüística em vigor.

Lobato, todavia, afirmou várias vezes que a linguagem "literaturizada", mesmo clara e simples, mas longe da realidade brasileira, não vendia. Como ainda era cedo para fazer "literatura de verdade" usando, predominantemente, na sintaxe e no léxico, a variante brasileira, apelou para "a mina", a literatura infantil. Esse propósito comercial de Lobato está registrado, também, na penúltima carta que enviou ao neto Rodrigo. Lá, diz ele, textualmente:

"Recebi sua carta de 11 do corrente, dizendo que está lendo o D. Quixote e já leu Reinações e gostou. Nesse ponto o avô está de acordo com o neto, porque eu também gosto muito desse livro - e tem sido uma mina de dinheiro. Essa mina um dia passará para as mãos de você e de Joyce, que são os meus únicos herdeiros - e é bom que você vá sabendo disso. Depois de Reinações você vai ler todos os outros, na ordem marcada, e irá verificando que o seu avô, como diz a Emília, é um

mais e vamos constantemente alterando nossa atitude ética, como alteramos nossa atitude lingüística, alargando nossos critérios de aceitabilidade social." 
danadinho para escrever histórias que toda a gente compra. A grande coisa é esta: produzir coisas que o mundo compra, porque se o mundo não compra a gente fica a chupar o dedo, com o bolso sempre vazio." (Cartas escolhidas: 268).

Lobato foi inteligente o suficiente para perceber a distância que havia entre a língua literária, praticada então no Brasil, e a realidade. Literatura para adultos que, conseqüentemente, tinha de ser escrita segundo a tradição e por isso, não venderia, e a intenção dele era "inundar o país de livros" (e o bolso de dinheiro, como vimos). Conseguiu, efetivamente, seu objetivo com a literatura infantil. Não sem antes, é verdade, trabalhar muito pela implementação e expansão da indústria gráfica do livro no Brasil.

Mesmo tendo sido cheia de conflitos a relação de Lobato com a linguagem, podemos admitir que um ponto coincidentente entre ele e o Modernismo foi a "simplificação" da linguagem, que anunciou já no início dos anos 20. Mesmo não tendo praticado cabalmente o que dizia, reconheceu que a linguagem tinha de ser o mais possível atualizada, contemporânea. A linguagem "literaturizada", ao gosto português dos séculos anteriores não atingia o leitor brasileiro, mesmo se fosse "simples e clara”. Esse ideal perseguido está mais vivo na sua literatura infantil. De modo geral, a linguagem de Lobato, depois de Urupês, é relativamente simples, clara e sempre marcada por neologismos, o que, como afirmou Pimentel Pinto (1994), constituiu seu estilo definitivo.

A "linguagem simples" de Lobato, no entanto, não é imitação da língua falada, pois ele não admitia interferência de uma modalidade na outra. A simplicidade era alcançada pelo uso de sintaxe descomplicada, de frases mais curtas e termos da oração dispostos em ordem direta, além de vocabulário atualizado, condizente com a realidade lingüística brasileira.

Segundo análise de Pimentel Pinto (Op. cit.: 55-6), em Urupês Lobato era ainda muito lusitano: usava sintaxe e até prosódia à moda européia. Os poucos neologismos que usou nesse livro, como "lusco-fuscou" e "tendenciadas", foram substituídos em edições posteriores à primeira, "numa evidente concessão aos puristas, que incluíam os neologismos entre os então chamados 'vícios de linguagem" " (Op. cit.). A partir desse livro, aos poucos, Lobato foi abandonando a norma européia, porque, segundo as declarações feitas a Rangel, ia percebendo o descompasso entre aquela linguagem e a realidade brasileira. 
Do que analisamos, vemos claramente que não foi somente o episódio Malfatti que afastou Lobato do Modernismo, mas ele mesmo com seus objetivos, em alguns pontos coincidentes e em outros completamente distantes daqueles desse movimento literário. Em todo o tempo, o modelo de linguagem de Lobato foi Camilo, mesmo na sua fase de maior simplicidade e de busca de um estilo brasileiro. Ao contrário, a linguagem praticada pelos modernistas, embora muito estilizada, tinha o falar do povo como fonte de inspiração. Nos escritos de Lobato, a fala tosca do Jeca era apenas mais um recurso usado na caracterização da personagem e jamais seria usada como fala padrão brasileira.

\section{Considerações finais}

Podemos concluir, assim, que a mudança de atitude lingüística de Lobato deveu-se a seus conflitos e contradições e também a motivos econômicos, talvez mais do que a conviç̧ões lingüísticas. As razões econômicas vieram da necessidade de atualizar a linguagem para vender livros, o que foi decisivo na sua mudança de atitude lingüística. De todo modo, não se pode deixar de reconhecer que o aproveitamento de fatores sociais e geográficos feitos pelo autor em seus textos o levaram a praticar uma linguagem (confundida até com uma língua) brasileira, é claro, diferente da portuguesa.

Mesmo com tantos problemas, podemos dizer que, indiretamente, Lobato contribuiu para a implantação da norma brasileira. Reconheceu e divulgou a dificuldade de compreensão e a difícil aceitação que a língua lusitanizante oferecia ao leitor brasileiro, e procurou escrever, pelo menos a literatura infantil, de acordo com princípios que permitissem certa aproximação da língua escrita com a realidade lingüística brasileira.

\section{Bibliografia}

CAVALHEIRO, E. (1955) Monteiro Lobato: vida e obra. São Paulo: Brasiliense (2v.).

LOBATO, J. B. M. (1944) A barca de Gleyre. São Paulo: Nacional. (1955) As idéias de Jeca Tatu. São Paulo: Brasiliense. 
. (1956) Críticas e outras notas. São Paulo: Brasiliense.

(1964) Cartas Escolhidas. São Paulo: Brasiliense.

PIMENTEL PINTO, E. (1978) O Português do Brasil: textos críticos e teóricos, 1- 1820/ 1920, fontes para teoria e história. Rio de Janeiro: Livros Técnicos e Científicos; São Paulo: Editora da Universidade de São Paulo.

. As relações de Lobato com a Gramática. In: Suplemento Cultural. $O$ Estado de $S$. Paulo, p. 6, ano II: 89, 9 jul. 1978.

. (1981) O Português do Brasil: textos críticos e teóricos, 2 - 1920/1945, fontes para teoria e história. Rio de Janeiro: Livros Técnicos e Científicos; São Paulo: Editora da Universidade de São Paulo.

. (1990) A gramatiquinha de Mário de Andrade: texto e contexto. São Paulo: Duas Cidades.

(org.) (1994) O escritor enfrenta a língua. São Paulo: FFLCH-USP.

PRETI, D. (1990b) Tradução e aceitabilidade social das formas lingüísticas. In: A Tradução: alvos e ferramentas. IV Encontro Nacional de Tradutores. Universidade São Paulo.

SODRÉ, N. W. (1976) História da Literatura Brasileira: seus fundamentos econômicos. 6. ed. Rio de Janeiro: Civilização Brasileira. 